\begin{abstract}
Iranica
Abstracta Iranica Revue bibliographique pour le domaine irano-aryen

Volume 32-33 | 2013

Comptes rendus des publications de 2009-2010
\end{abstract}

\title{
Wouter F. Henkelman. Xerxes, Atossa and the Persepolis Fortification Archive
}

\section{Astrid Nunn}

\section{(2) OpenEdition \\ 1 Journals}

\section{Édition électronique}

URL : http://journals.openedition.org/abstractairanica/40294

DOI : 10.4000/abstractairanica.40294

ISSN : 1961-960X

Éditeur :

CNRS (UMR 7528 Mondes iraniens et indiens), Éditions de l'IFRI

\section{Édition imprimée}

Date de publication : 1 décembre 2013

ISSN : 0240-8910

\section{Référence électronique}

Astrid Nunn, "Wouter F. Henkelman. Xerxes, Atossa and the Persepolis Fortification Archive ", Abstracta Iranica [En ligne], Volume 32-33 | 2013, document 77, mis en ligne le 01 juillet 2016, consulté le 26 septembre 2020. URL : http://journals.openedition.org/abstractairanica/40294 ; DOI : https://doi.org/ 10.4000 /abstractairanica.40294

Ce document a été généré automatiquement le 26 septembre 2020.

Tous droits réservés 


\title{
Wouter F. Henkelman. Xerxes, Atossa and the Persepolis Fortification Archive
}

\author{
Astrid Nunn
}

\section{RÉFÉRENCE}

Wouter F. Henkelman. « Xerxes, Atossa and the Persepolis Fortification Archive ». The Netherlands Institute for the Near East Leiden, The Netherlands Institute in Turkey Istanbul (NIT), Annual Report 2010, p. 27-33.

1 Article de synthèse sur les tablettes des Fortifications de Persépolis tout en donnant un exemple sur la confrontation des sources grecques avec les informations données par les tablettes. Atossa, mère de Xerxès, est décrite par Hérodote comme très puissante bien avant l'accession de son fils au trône en 486 av. J.-C. Les tablettes donnent une image tout à fait contraire.

\section{AUTEURS}

\section{ASTRID NUNN}

Université de Munich 